\title{
Targeting Mineral Resources with Remote Sensing and Field Data in the Xiemisitai Area, West Junggar, Xinjiang, China
}

\author{
Lei Liu ${ }^{1,2}$, Jun Zhou ${ }^{1,2}$, Dong Jiang ${ }^{3}{ }^{*}$, Dafang Zhuang ${ }^{3}$, Lamin R. Mansaray ${ }^{1}$ and Bing Zhang ${ }^{4}$
}

1 Key Laboratory of Western Mineral Resources and Geological Engineering of Ministry of Education, School of Earth Sciences and Resources, Chang'an University, Xi'an 710054, China;

E-Mails: liul@chd.edu.cn (L.L.); zhoujun@chd.edu.cn(J.Z.); 1.mansaray @ slari.gov.sl (L.R.M.)

2 Lanzhou AuriferouStone Mining Services Co., Ltd., Lanzhou 730030, China

3 LREIS, Institute of Geographic Sciences and Natural Resources Research, Chinese Academy of Sciences, Beijing 100101, China; E-Mail: zhuangdf@lreis.ac.cn

4 Geological Brigade 7 of Xinjiang Bureau of Geology and Mineral Resources, Wusu 833000, China; E-Mail: zhangbing@163.com

* Author to whom correspondence should be addressed; E-Mail: jiangd@1reis.ac.cn; Tel.: +86-10-6488-9433; Fax: +86-10-6485-5049.

Received: 30 April 2013; in revised form: 12 June 2013 / Accepted: 13 June 2013 / Published: 25 June 2013

\begin{abstract}
The Xiemisitai area, West Junggar, Xinjiang, China, is situated at a potential copper mineralization zone in association with small granitic intrusions. In order to identify the alteration zones and mineralization characteristics of the intrusions, Landsat Enhanced Thematic Mapper (ETM+) and Quickbird data of the study area were evaluated in mapping lithological units, small intrusions, and alteration zones. False color composites of the first principal component analyses (PCA1), PCA2, and PCA4 in red (R), green (G), and blue (B) of the ETM+ image, and relevant hue-saturation-intensity (HSI) color model transformations, were performed. This led to the identification of lithologic units and discrimination of granitic intrusions from wall-rocks. A new geological map was generated by integrating the remote sensing results with two internally published local geologic maps and field inspection data. For the selected region, false color composites from PCA and relevant HSI-transformed images of the Quickbird data delineated the details of small intrusions and identified other unknown similar intrusions nearby. Fifteen separate potash-feldspar granites and three separate hornblende biotite granites were identified using ETM+ and Quickbird data. The principal component analysis-based Crosta technique was employed to discriminate alteration minerals. Some of the mapped alteration zones
\end{abstract}


using the Crosta technique agreed very well with the known copper deposits. Field verification led to the discovery of three copper mineralizations and two gold mineralizations for the first time. The results show that the PCA and HSI transformation techniques proved to be robust in processing remote sensing data with moderate to high spatial resolutions. It is concluded that the utilized methods are useful for mapping lithology and the targeting of small intrusion-type mineral resources within the sparsely vegetated regions of Northwest China.

Keywords: West Junggar; ETM+; Quickbird; principal component analyses; HSI color model; Crosta technique

\section{Introduction}

Nation-wide geological mapping and mineral resource investigations in China are typically carried out by field traverses. The China Geological Survey suggests the average distance between two adjacent traverses should be 3 to $4 \mathrm{~km}$ in areas with good conditions for geological mapping at the 1:250,000 scale [1]. Furthermore, the distance should be 500 to $600 \mathrm{~m}$ for geological mapping at a scale of 1:50,000 [2]. Although remote sensing has been mentioned in these standards, it is regarded as a less important approach and the application has been restricted by the image processing and interpretation skills of the geologists. As a consequence, geological mapping in West China is time-consuming, expensive, difficult, and even dangerous. In addition, lithologies are often mapped coarsely at scales ranging from 1:50,000 to 1:250,000 [3], which leads to small felsic-ultramafic intrusions often being omitted during field-based geological mapping [4]. It is believed that $\mathrm{Ni}-\mathrm{Cu}-\mathrm{Mo}$ ores, such as the Jinchuan Ni-Cu sulfide deposit, Jinduicheng Mo deposit, and Dexing Cu-Mo deposit, are preferably hosted by small-sized intrusions [5]. Therefore, it is important for the mineral resource exploration-orientated investigation to locate unknown small intrusions during the reconnaissance stage.

Remote sensing has been extensively used for lithological mapping and mineral exploration [6-18]. The multispectral data of the Landsat Thematic Mapper (TM) and the Enhanced Thematic Mapper (ETM+) have been the most commonly used data sources for geologic applications in the past three decades with promising results [7,16-22]. However, the 30-m spatial resolution of ETM+ multispectral data is too coarse to identify small intrusions of sizes less than several hundred square meters. The panchromatic band (15-m spatial resolution) fusion can largely enhance the ability of ETM+ multispectral bands to outline certain small intrusions roughly as done in this study. High-resolution data, though, need using for the detailed demarcation and the scanning of nearby smaller analogs.

Quickbird has four multispectral bands and a panchromatic channel covering the $0.45-0.90 \mu \mathrm{m}$ range, with spatial resolutions of $2.44 \mathrm{~m}$ and $0.61 \mathrm{~m}$, respectively. Quickbird data have been used in geological mapping and hazard assessing in recent years [23-26].

The Western Junggar region, located between Altay Shan and Tianshan, extends westward to the Junggar-Balkhash system adjacent to Kazakhstan, and eastward to the Junggar Basin in China (Figure 1) [27]. Carboniferous granitic intrusions are widespread throughout Western Junggar [27]. The structural and thermodynamic conditions show that western Junggar has large mineralization 
potential, identified by many ore deposits (mostly gold and copper) such as Hatu (quartz vein-related gold deposit) [28] and Baogutu (porphyry-type copper deposit with gold and molybdenum as by-products) [27]. The Tuketuke porphyry copper deposit and the Jafushaersu molybdenum mineralization were found in recent years; these discoveries were made based on the reconnaissance of the Baogutu surroundings by alteration mineral mapping using remote sensing data and the following ground inspection (Figure 1) [4,29].

Figure 1. (a) Generalized geological map of Western Junggar, NW China, showing the distribution of the intrusions, ophiolite belts and main faults [27]; (b) Geological map of the study area after the internally published regional geological maps with codes L-45-VIII and L-45-XIV [30,31]. Q, Quaternary; N, Neogene; C, Carboniferous; D, Devonian.
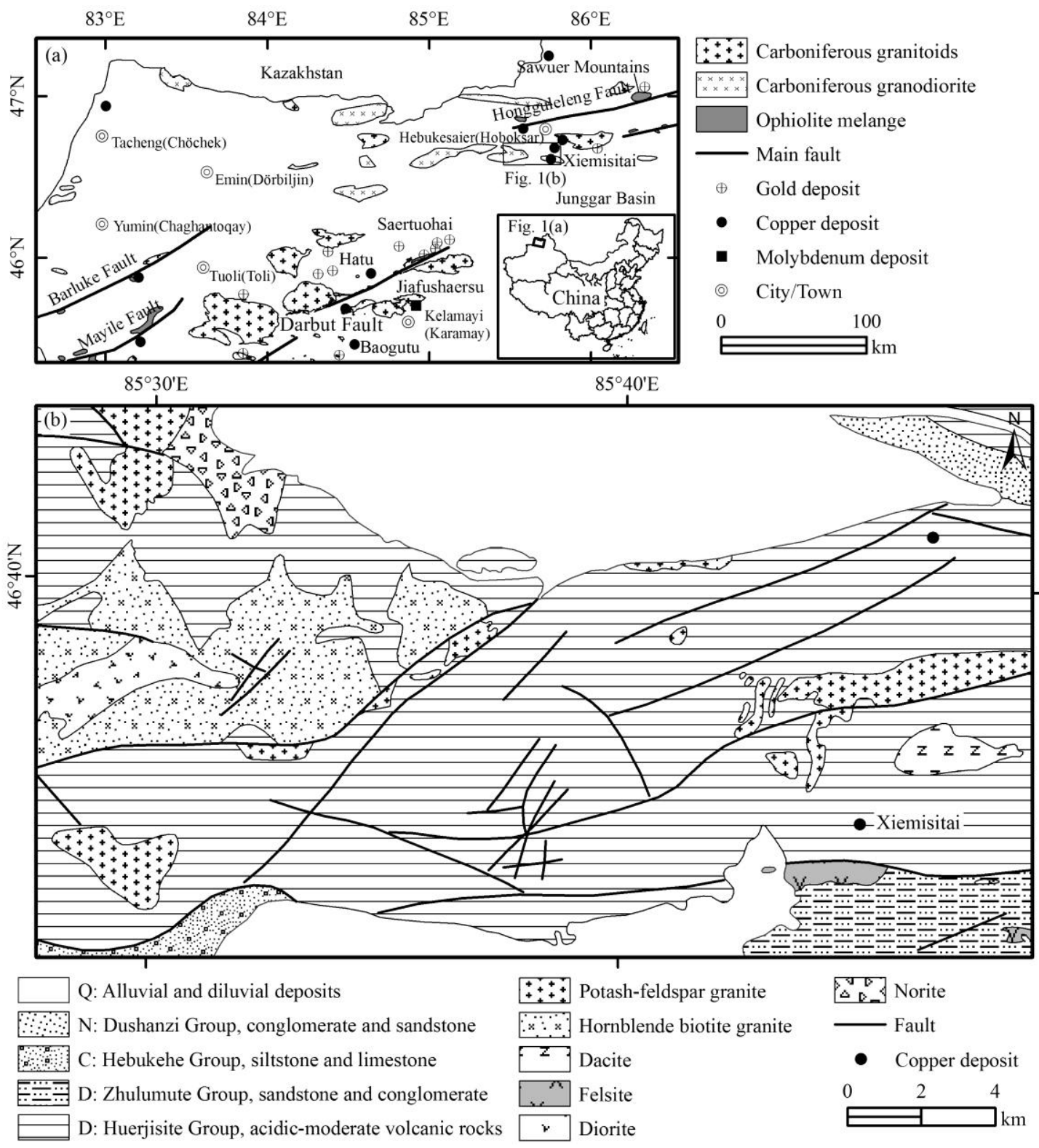

The Xiemisitai area, located in Northwestern Junggar, has strong potential for copper deposits (Figure 1). The objectives of this research were as follows: (1) process and interpret the ETM+ imagery by integrating the principal component analysis with hue-saturation-intensity (HSI) color 
model transformation methods to outline the small intrusions and generate a new geological map for the Xiemisitai area; (2) use the higher resolution Quickbird data to delineate the details of small intrusions and find other unknown similar intrusions nearby in the key region; (3) identify the alteration zones and reveal the alteration patterns and mineralization characteristics of the relevant intrusions.

\section{Geological Settings}

The Xiemisitai area is situated between the Darbut Suture and the Hongguleleng Suture (Figure 1(a)). It is much closer $(10 \mathrm{~km})$ to the Hongguleleng suture, which is marked by an ophiolite zone (mostly dismembered harzburgite and cumulate) continually extending approximately $100 \mathrm{~km}$ [32,33]. The ophiolite was believed to have evolved by the Middle Ordovician along Hongguleleng since it was overlaid by Middle Ordovician andesites (the Bulukeqi Formation) [34] and two samples of the ophiolite yielded their respective radiometric ages of $626 \pm 25 \mathrm{Ma}$ and $444 \pm 27 \mathrm{Ma}$ (Sm-Nd isochrones) [35].

Acidic volcanic rocks and granitic intrusions are widespread in the region (Figure 1(a)). The known mineral deposits in the region are related to igneous activities [27]. Most of the studies about regional mineralizations were concentrated on the Sawuer Mountains [36,37]. The Kuoerzhenkuola gold deposit was formed in the structural environment of an island arc of the Late Palaeozoic Era and controlled by the cryptoexplosion breccia and volcanic apparatus [36]. The Buerkesidai gold deposit was considered to be supergene magma and a structurally altered rock-type gold deposit [37]. However, gold and copper deposits in the Xiemisitai area have rarely been reported to date. The Xiemisitai copper deposit is a volcanic copper deposit, which is controlled by a caldera fracture system, superimposed by the EW-striking regional faults (Figure 1) [38].

The oldest rocks of the study area fall within the Huerjisite Group (Middle Devonian), which consists of moderately acidic volcanic rocks (Figure 1(b)). The Zhulumute Group (Upper Devonian) contains sandstone, conglomerate and siltstone, which are mainly distributed in the southeast of the study area. The Hebukehe Group (Lower Carboniferous) contains calcareous siltstone and limestone. The Dushanzi Group (Neogene) consists of conglomerate and sandstone. The quaternary sediments are mainly composed of alluvium and diluvium. The granitic intrusions are dominated by potash-feldspar granites and hornblende biotite granites. Tectonism is dominated by nearly NE-, NWW- and NEE-trending faults. The alteration of the Xiemisitai copper deposit is typified by extensive malachite, relatively stronger chloritization, epidotization, and silicification [38].

\section{Data and Methods}

Landsat 7 ETM+ data (145/27 path/row, acquisition date 27 June 2000) of the Xiemisitai area were used for this study. Additionally, Quickbird data acquired on 6 January 2008 were used for the selected area. Pre-processing of the satellite imagery included both geometric and radiometric corrections. The images were geometrically corrected by picking ground control points (GCPs) from 1:50,000 scaled topographic sheets and GPS points that were taken during field work. The radiometric correction was implemented using the method suggested by [39], in which calibrated Digital Numbers (DNs) were converted to Top-Of-Atmosphere (TOA) reflectance.

In this study, a series of image processing methods were used. First, image enhancement methods including principal component analysis (PCA) [40] and HSI color model transformation [41] were 
applied to process ETM+ data to outline the small intrusions and generate a new geological map for the Xiemisitai area. Second, for the selected region with small intrusions identified, PCA and HSI color model transformation methods were used to process Quickbird data to delineate the details of small intrusions and find other unknown similar intrusions nearby. Third, the alteration minerals were mapped using the Crosta technique [7,9,19], a principal component analysis-based method using the association of bands $1,4,5$, and 7 for extracting hydroxyl-bearing and carbonate minerals and that of bands 1, 3, 4, and 5 for iron oxides. In targeting new mineralization prospects, the existing geological controls (as derived from the geological map) of the study area were overlapped with the remote sensing results obtained herein. The geology and remote sensing overlaps deduced were verified on the ground through field inspection. This eventually led to the discovery of some new mineralization outcrops in the Xiemisitai area, Western Junggar, Xinjiang, China.

\section{Results and Discussion}

\subsection{Lithological Mapping}

\subsubsection{Principal Component Analysis}

Principal components analysis (PCA) is an image enhancement technique, which reduces the dimensionality of data and segregates noise components [40]. PCA has been used widely with multispectral remote sensing images to identify lithologic units $[4,8,10]$. In this study, standard PCA has been applied to the ETM+ data to enhance the lithological differences. The transformation was applied using the related covariance matrix [17].

The image eigenvectors and eigenvalues obtained from PCA are indicated in Table 1. The first principal component (PCA1) is composed of a positive weighting from all six bands. PCA1 accounts for $83.8 \%$ of the total variance of the data (Table 1). Eigenvector loadings for PCA2 indicate the difference between bands 1,2 , and 3 , and bands 5 and 7 . No useful information can be extracted from PCA3 because of the large band 4 eigenvector $(-0.852)$ in comparison to the remaining bands. Based on eigenvector loadings for bands $1(-0.603), 2(-0.373)$ and $3(0.647)$ in PCA4, the values of bands 1 and 2 have negative signs compared to band 3, which is in opposite (positive) sign (Table 1). From image interpretation, the potash-feldspar granites have relatively high reflectance in band 3 and low reflectance in bands 1 and 2. We can therefore predict that potash-feldspar granites can be distinguished by bright pixels in PCA4. As suggested by the greatest loadings for bands $5(-0.581)$ and 7 (0.511), and the opposite signs in Table 1, the spectral information of hydroxyls should be contained in PCA5. PCA6 is the noisiest component and does not contain useful information.

Figure 2 shows false color composites of PCA1, PCA2, and PCA4, in red (R), green (G), and blue (B) images of the study area, which present a well-differentiated result for mapping the lithological units of the study area. The Huerjisite Group is a mixture of green and blue. The Zhulumute Group is in mixture of light green and coral in the southeast region of the study area. The Hebukehe Group is a mixture of yellow and dark blue. The potash-feldspar granites are a mixture of cyan and lilac, while hornblende biotite granites are shown in pale yellow (Figure 2). 
Table 1. Eigenvector matrix of the principal component analysis for the six Landsat 7 Landsat Enhanced Thematic Mapper (ETM+) bands studied.

\begin{tabular}{cccccccc}
\hline Input Bands & Band1 & Band2 & Band3 & Band4 & Band5 & Band7 & Eigen Values (\%) \\
\hline PCA1 & 0.229 & 0.322 & 0.506 & 0.234 & 0.551 & 0.479 & 83.8 \\
PCA2 & -0.428 & -0.406 & -0.493 & 0.088 & 0.531 & 0.345 & 9.4 \\
PCA3 & 0.059 & -0.038 & 0.049 & -0.852 & -0.121 & 0.502 & 5.0 \\
PCA4 & -0.603 & -0.373 & 0.647 & 0.099 & -0.246 & 0.090 & 1.0 \\
PCA5 & 0.126 & 0.030 & -0.241 & 0.444 & -0.581 & 0.511 & 0.5 \\
PCA6 & -0.618 & 0.768 & -0.147 & -0.062 & -0.053 & 0.026 & 0.1 \\
\hline
\end{tabular}

Figure 2. Principal components analysis (PCA1, PCA2, and PCA4 in the RGB) image of $\mathrm{ETM}+$ data.

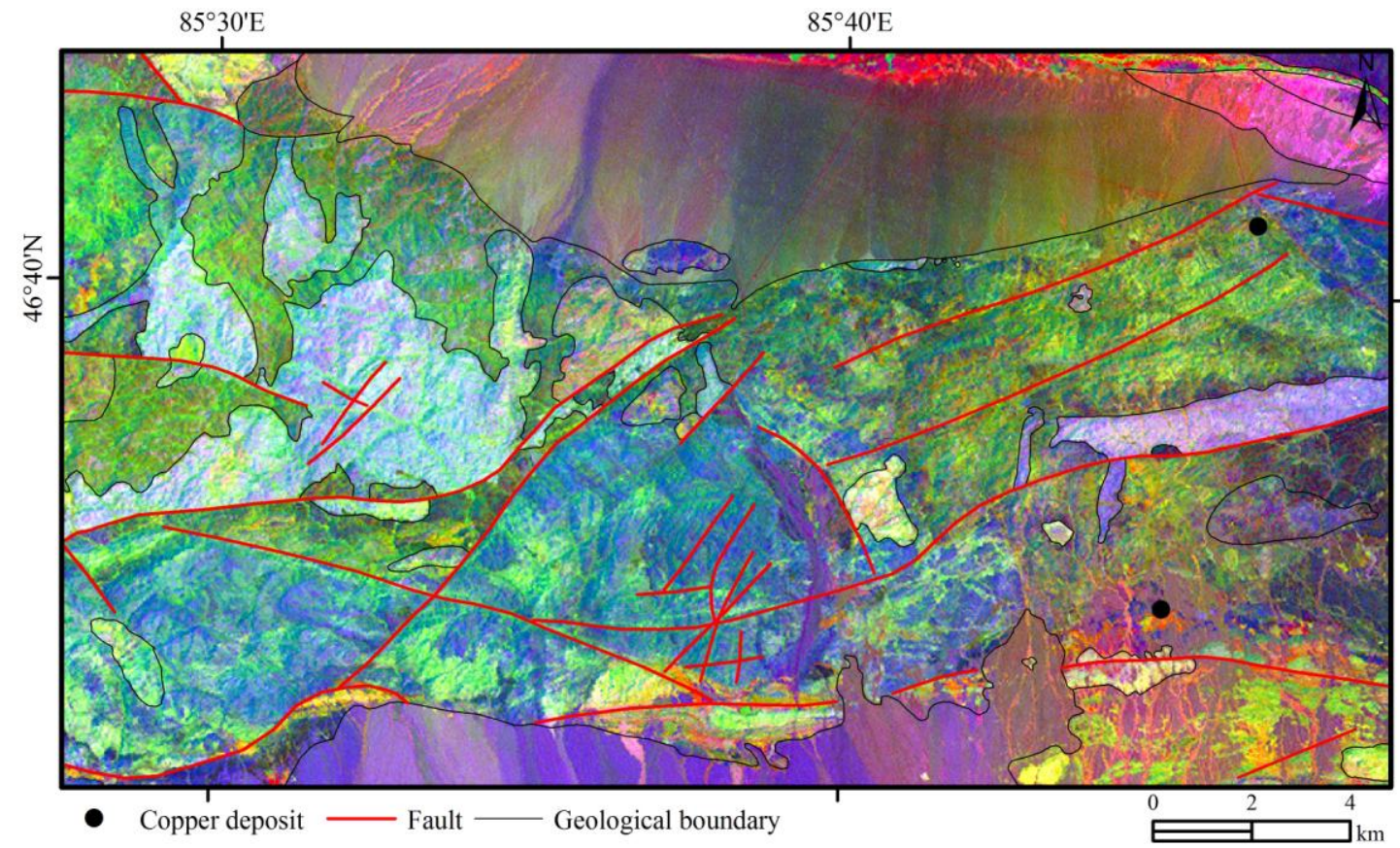

\subsubsection{Hue-Saturation-Intensity (HSI) Color Model Transformation}

The hue-saturation-intensity (HSI) color model allows independent control over hue, saturation, and intensity, the quantities of which are definitely measurable and easily interpretable [41]. As we know through trial and error studies, transforming some PCA combinations from RGB to HSI space can properly enhance the differences among lithological units. In this study, PCA1, PCA2, and PCA4 were transformed from RGB to HSI space, and the false color composite imagery of I, H, and S in RGB allowed discrimination of nearly all the lithologic units (Figure 3).

The Huerjisite Group is identified by a blue color. The Zhulumute Group is a yellowish-green color. The Hebukehe Group is a dark blue color. The potash-feldspar granites were well separated from adjacent rocks by a purple-red color, and the hornblende biotite granites were beige (Figure 3). The potash-feldspar granites and the Huerjisite Group were discriminated better in the HSI image than in the PCA image. 
Figure 3. PCA1, PCA2 and PCA4 transformed to HSI space with $\mathrm{I}, \mathrm{H}$, and $\mathrm{S}$ in RGB image.

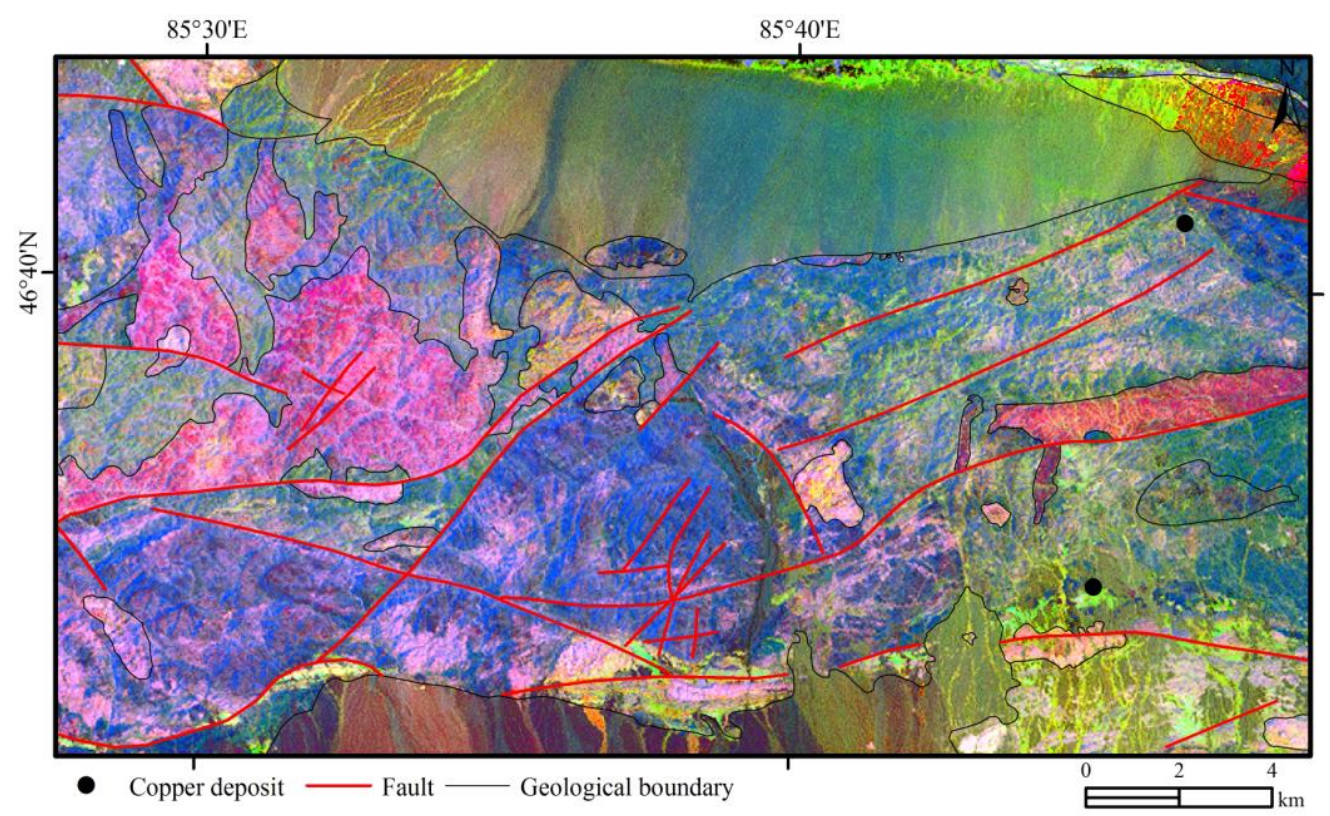

Figure 4. Geologic map of Xiemisitai modified after integrating the results of remote sensing data with two internally published geologic maps and field inspection data (The differences from the original geological maps (Figure 1(b)) and on the basis of image interpretation (Figures 2 and 3) and ground confirmation are here labeled with 1-6 and (1)-(7), however, some may not be clear due to the scale reduction here). Q, Quaternary; $\mathrm{N}$, Neogene; C, Carboniferous; D, Devonian.

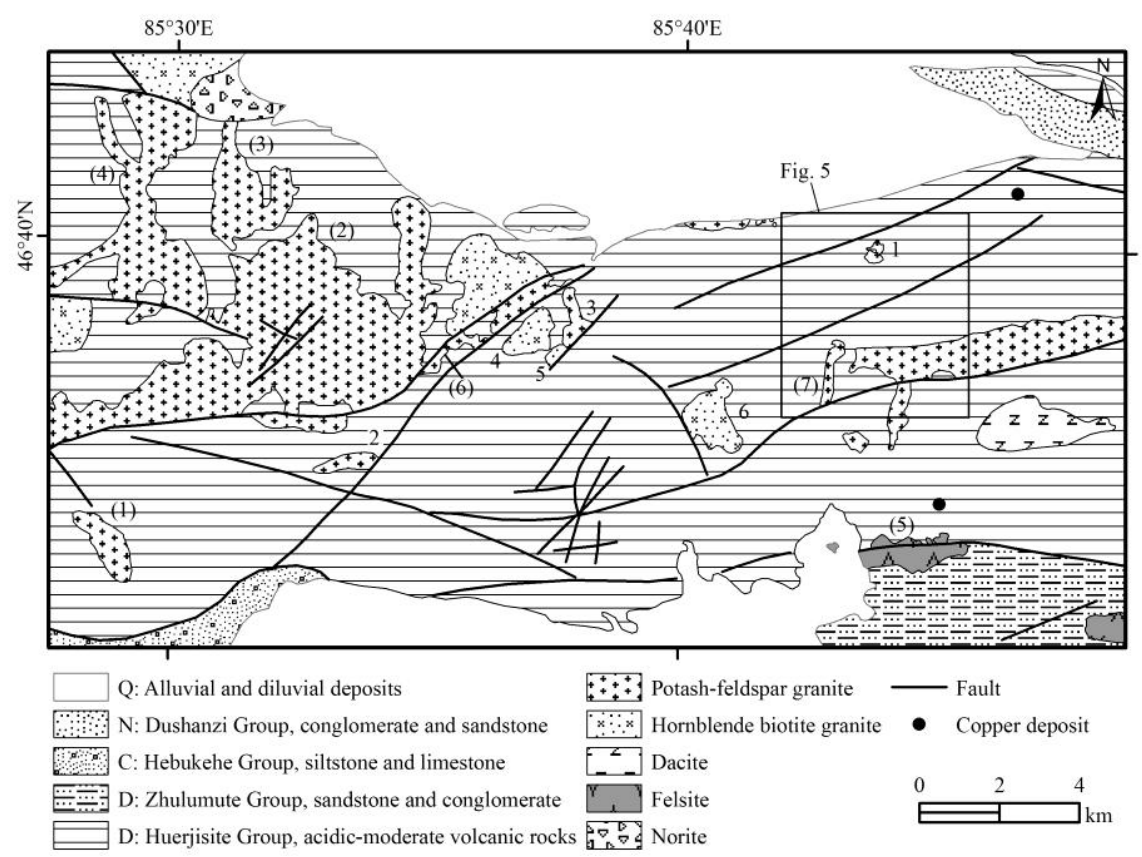

Through geological interpretation, the faults and geologic boundaries have been revised and three separate potash-feldspar granites and three separate hornblende biotite granites have been identified and labeled in Figure 4 with 1-6 (Figures 1-4). A new geologic map of the Xiemisitai area (the 
specific modifications are labeled in Figure 4 with (1)-(7)) was created by integrating the results of a false-color composite image of PCA1, PCA2, and PCA4 (in RGB) with the false-color composite image of the HSI color model transformation, two internally published local geologic maps (codes L-45-VIII and L-45-XIV) and field inspection data (Figure 4).

\subsection{Identification of Small Intrusions Using Quickbird Data}

Good results, including small intrusion discrimination, were obtained using ETM+ data in geologic mapping. However, the 30-m spatial resolution of ETM+ multispectral data is too coarse to identify small intrusions or map their details. A major region was selected due to its close proximity to two copper deposits, copper geochemical anomalies, and the identified small potash-feldspar granite (Labeled 1 in Figure 4). Although some small intrusions near the identified small potash-feldspar granite have been outlined in the ETM+ image, the boundaries are not very sharp.

PCA and HSI color model transformation methods were used to process Quickbird data to better outline the small intrusions and/or their details. Figure 5(a) shows false color composite of PCA1, PCA2, and PCA4 (in RGB) image of the selected area. The Huerjisite Group is in green. The potash-feldspar granites are white. Though affected by snow (red in Figure 5(a)), twelve separate small potash-feldspar granites were identified primarily by their distinct false color and tone. The smallest potash-feldspar granite body is only $0.0004 \mathrm{~km}^{2}$ in area, which is beyond the detection capabilities of the ETM+ sensors, and therefore, can only be identified by using Quickbird.

Figure 5. Major small intrusions and their details in the target area (confirmed in situ). (a) PCA1, PCA2, and PCA4 (in RGB) image of Quickbird data; (b) PCA2, PCA3, and PCA4 transformed to HSI space with I, H, and S (in RGB) image (the areas depicted in Figure 5 are given in Figure 4).

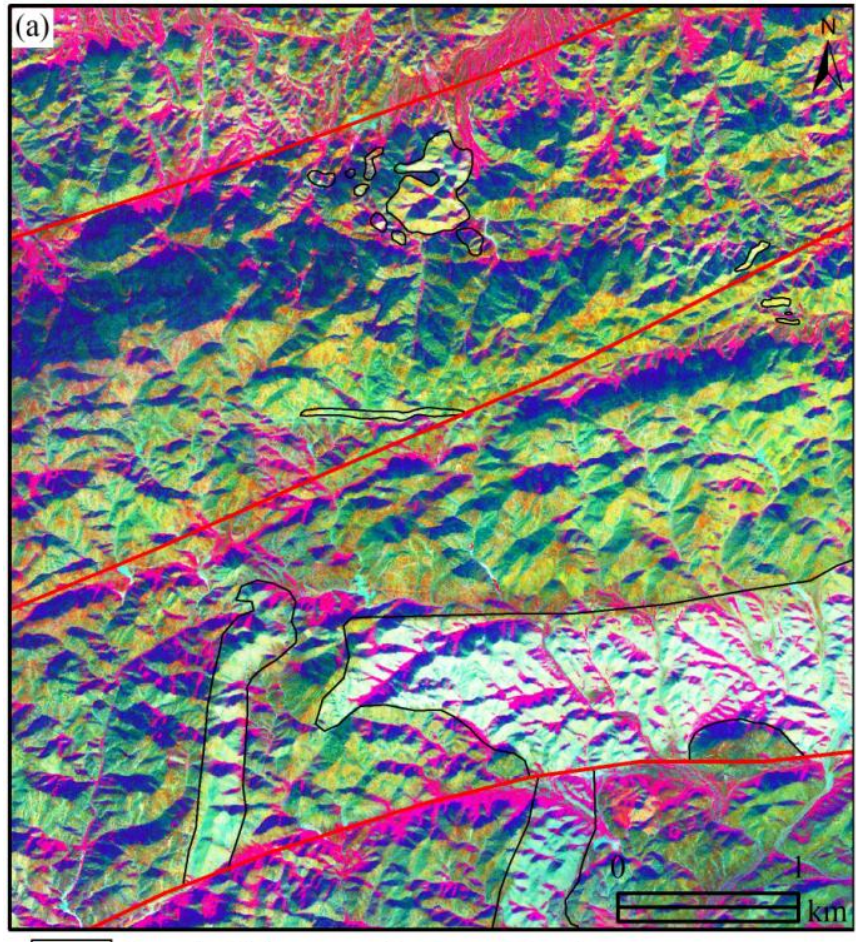

Potash-feldspar granite — Fault

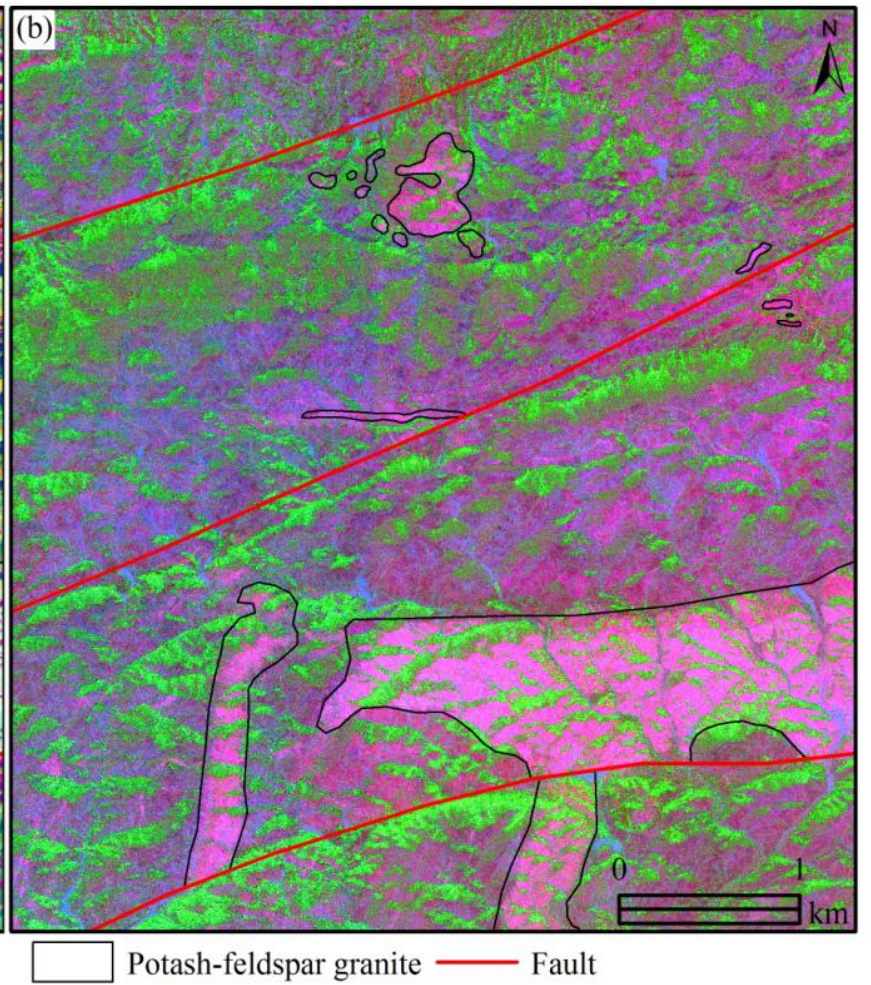

Potash-feldspar granite $\longrightarrow$ Fault 
PCA2, PCA3, and PCA4 were transformed from RGB to HSI space and the false color composite imagery of $\mathrm{I}, \mathrm{H}$, and $\mathrm{S}$, in RGB, further delineated the difference in color, texture, and shape for the recognition of small intrusions (Figure 5(b)). Specifically, the potash-feldspar granites are pink with a short, thick-stripe texture, and a round-shape, which can be easily identified. The HSI image indicates that there may be other similar bodies in this region.

\subsection{Alteration Mineral Mapping}

The Crosta technique is also known as a feature-oriented principal component selection, which has been widely used in mineral exploration to identify the diagnostic features of hydroxyl minerals, carbonate bearing minerals and iron oxides $[7,9,19,22]$.

The PCA4s of two separate four-band associations (i.e., ETM+ bands 1, 3, 4, and 5, or bands 1, 4, 5 , and 7) using the Crosta technique (Tables 2 and 3) primarily contain the information concerning iron oxides and hydroxyls because the greatest loadings are connected to either band $3(-0.531)$ and band 1 (0.837), or bands $5(-0.638)$ and $7(0.610)$. However, relevant images mapping iron oxides and hydroxyls as bright pixels need to be inversed because both loadings for band 3 in PCA4 (the 1, 3, 4 and 5 bands; Table 2) and band 5 in PCA4 (for the 1, 4, 5, and 7 bands; Table 3) are marked by a minus sign. The extracted alteration mineral information was overlaid on a natural color composite (ETM+ bands 3 (R), 2 (G), 1 (B)) (Figure 6). The anomalies for both hydroxyls and iron oxides were classified by a threshold of $\mu+2 s$ and the coloring was red for the former and blue for the latter. Note: $\mu$ and s represent the mean value and standard deviation of the relevant principal component images, respectively.

Table 2. The Eigenvector matrix values of PCA for the 1, 3, 4, and 5 bands.

\begin{tabular}{cccccc}
\hline Input Bands & Band1 & Band3 & Band4 & Band5 & Eigen Values (\%) \\
\hline PCA1 & 0.278 & 0.618 & 0.305 & 0.669 & 83.4 \\
PCA2 & -0.470 & -0.579 & 0.305 & 0.592 & 10.8 \\
PCA3 & 0.037 & 0.005 & 0.902 & -0.431 & 4.6 \\
PCA4 & 0.837 & -0.531 & 0.030 & 0.129 & 1.3 \\
\hline
\end{tabular}

Table 3. The Eigenvector matrix values of PCA for the 1, 4, 5, and 7 bands.

\begin{tabular}{cccccc}
\hline Input Bands & Band1 & Band4 & Band5 & Band7 & Eigen Values (\%) \\
\hline PCA1 & 0.240 & 0.289 & 0.705 & 0.602 & 85.8 \\
PCA2 & -0.017 & 0.853 & 0.094 & -0.513 & 7.7 \\
PCA3 & -0.954 & -0.024 & 0.296 & 0.046 & 5.6 \\
PCA4 & -0.180 & 0.434 & -0.638 & 0.610 & 0.9 \\
\hline
\end{tabular}

The iron oxides mainly occur in the potash-feldspar granite (blue color) because of the spectral characters of potash-feldspar granite in the visible bands (Figure 6). All of the hydroxyls are located in the proximity of granitic intrusions and the main lineaments. Some of the alteration zones mapped using the Crosta technique agreed very well with the known copper deposits in the Xiemisitai area. 
Figure 6. Color composites (ETM+ bands 3 (R), 2 (G), 1 (B)) overlaid with the remote-sensing anomalies using the Crosta technique (the labeled sites correspond to those highlighted in Table 4).

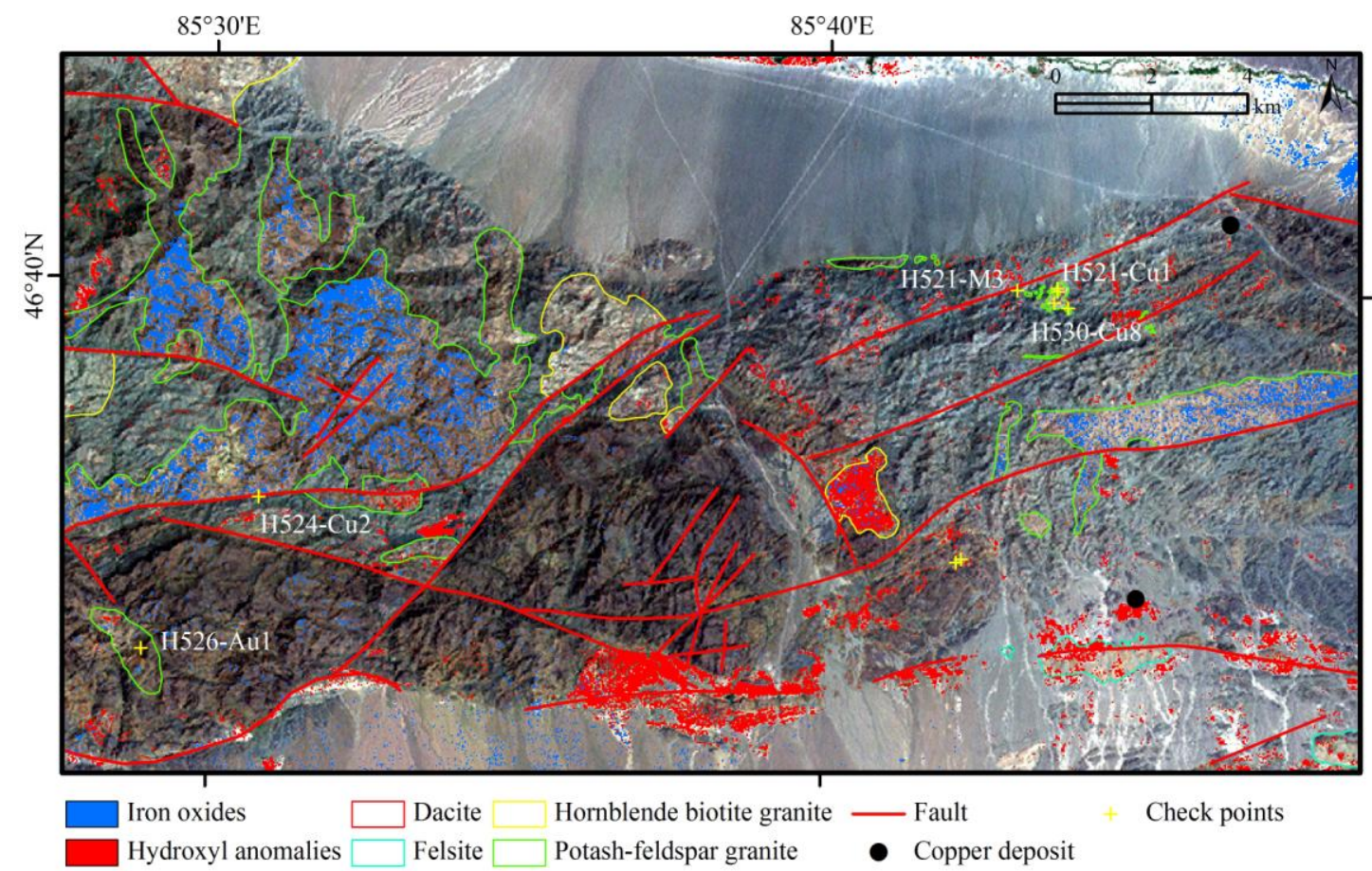

\subsection{Field Inspection and Studies}

To verify the results, field reconnaissance was carried out between July and August 2009. The check-points were recorded using a portable GPS with an average accuracy of $5 \mathrm{~m}$. All of the modified geological boundaries (labeled with (1)-(7) in Figure 4) and identified small intrusions (labeled with 1-6 in Figure 4) were confirmed in the field.

Four major targets for mineral exploration were checked in the field. A field investigation revealed that the contact zones between the intrusions and wall-rock were typified by the intensive silicification plus chloritization and epidotization. The copper mineralization was developed along the alteration zones, which are tens of meters in width.

Small intrusions and mapped alteration zones agreed very well with the field GPS locations of alteration zones in the study area (Table 4, Figure 6). Laboratory analysis was made for some selected samples from the alteration zones. All of the samples were analyzed for $\mathrm{Ag}, \mathrm{Cu}, \mathrm{Pb}, \mathrm{Zn}, \mathrm{Cr}, \mathrm{Co}, \mathrm{Mn}$, Mo, Ni, and W at the Xi' an Mineral Resources Supervision Center, Chinese Ministry of Lands and Resources, by using inductively coupled plasma-atomic emission spectroscopy (ICP-AES). Some selected samples were analyzed for $\mathrm{Au}$ and $\mathrm{Cu}$ using atomic absorption spectrum (AAS) and inductively coupled plasma (ICP) emission spectroscopy, respectively. According to the results, three copper mineralizations and two gold mineralizations were discovered for the first time (Table 4, Figure 6).

This result shows that the lithological mapping and alteration mineral maps derived from this study revealed new mineral exploration targets in small granitic intrusions that could be very promising indicators for copper and gold mineral assemblages. Therefore, further analysis and fieldwork need to be undertaken for these identified potential mineral exploration targets. 
Table 4. Descriptions and laboratory analysis results of field surveyed points with hydroxyl anomalies (the points described here correspond to those highlighted in Figure 6).

\begin{tabular}{|c|c|c|c|}
\hline \multirow{2}{*}{ Sample NO. } & \multicolumn{2}{|c|}{ Components } & \multirow{2}{*}{ Description } \\
\hline & $\mathrm{Cu}(\%)$ & Au $\left(10^{-6}\right)$ & \\
\hline H521-Cu1 & 0.2 & & $\begin{array}{l}\text { The sample was collected from altered potash-feldspar } \\
\text { granite that is } 550 \mathrm{~m} \text { in length and } 300 \mathrm{~m} \text { in width. } \\
\text { Malachite could be observed around dark minerals such as } \\
\text { hornblende. }\end{array}$ \\
\hline $\mathrm{H} 521-\mathrm{Cu} 2$ & 0.37 & & $\begin{array}{l}\text { Located in the south side of } \mathrm{H} 521-\mathrm{Cu} 1(100 \mathrm{~m}) \text {. } \\
\text { The sample was collected from the contact zone between } \\
\text { intrusion and wall-rock with silicification, chloritization } \\
\text { and scattered malachite. }\end{array}$ \\
\hline H521-M3 & 0.85 & 0.68 & $\begin{array}{l}\text { The outer contact zone of the potash-feldspar granite stock } \\
\text { is typified by silicification and chloritization. Malachite } \\
\text { distributed regularly with the alteration. }\end{array}$ \\
\hline H530-Cu8 & 0.13 & & $\begin{array}{l}\text { The sample was collected from the same potash-feldspar } \\
\text { granite with } \mathrm{H} 521-\mathrm{Cu} 1 \text { and } \mathrm{H} 521-\mathrm{Cu} 2 \text {. Malachite could } \\
\text { be observed along chloritization which is ubiquitous in } \\
\text { the granite. }\end{array}$ \\
\hline $\mathrm{H} 524-\mathrm{Cu} 2$ & 0.016 & 0.28 & $\begin{array}{l}\text { The outer contact zone (dipping SE } 300^{\circ} \text { with a } 60^{\circ} \text { angle) } \\
\text { of the potash-feldspar granite has intensive epidotization. } \\
\text { Malachite and chalcopyrite could be observed. }\end{array}$ \\
\hline H526-Au1 & & 0.23 & $\begin{array}{l}\text { The sample was collected from the potash-feldspar granite } \\
\text { with intensive silicification. }\end{array}$ \\
\hline
\end{tabular}

\subsection{Discussion}

A series of image processing techniques, including principal components analysis, false color composites using HSI layers, Crosta alteration mineral mapping have led to identifying mineralized small intrusions.

The false color composites of PCA1, PCA2, and PCA4 of ETM+ data in RGB images showed the different lithological units of the study area in different colors. The potash-feldspar granites are a mixture of cyan and lilac, while hornblende biotite granites are pale yellow (Figure 2).

The HSI color model allows independent control over hue, saturation, and intensity, which is an ideal tool for developing image processing algorithms based on color descriptions [41]. In fact, certain applications using the HSI color model have been described previously for other applications, e.g., medical image enhancement [42], burned land mapping [43], etc. In this study, PCA1, 2, and 4 were transformed from RGB to HSI space, and the false color composite imagery of I, H, and S, in RGB, allowed discrimination of nearly all the lithologic units (Figure 3). The potash-feldspar granites were well separated from adjacent rocks by a purple-red color, and the hornblende biotite granites were beige (Figure 3).

The capability of ETM+ data to discern the geologic features discussed herein can be ascribed to three important reasons. Firstly, the ETM+ data is well suited for investigating materials associated with weathering or mass wasting which often makes an altered mineralization zone much wider or a 
small intrusion larger. Secondly, the panchromatic band can effectively enhance the general resolution of ETM+ images through data fusion. And lastly, the higher spectral resolution is helpful to outline objects with diagnostic features in the VNIR and SWIR intervals. However, accurate shape or details, e.g., recognizing the tongues or small dikes for a small intrusion need higher spatial resolution images.

Therefore, PCA and HSI color models were also used to process Quickbird data to outline the details of small intrusions and find other unknown similar intrusions in the key region, with small intrusions identified by ETM+ data. The potash-feldspar granites are white in the false color composite image of PCA1, PCA2, and PCA4 (in RGB; Figure 5(a)). Specifically, the potash-feldspar granites are pink with a short thick-stripe texture and a round-shape, which can be better identified in the HSI transformed image (Figure 5(b)).

The Crosta technique assisted with identifying the location of the hydroxyls in proximity of the granitic intrusions and main faults (Figure 6). The anomalies are sparsely distributed and aligned linearly or clustered in irregular shapes. From synthetic analysis, new mineral exploration targets were located based on the overlap of the small intrusions, alteration anomalies, and geologic information (Figure 6).

\section{Conclusions}

West Junggar, lying in the northwesternmost part of China, is bounded on the north by the Altay Shan Mountains and on the south by the Tianshan Mountains. Many copper-gold associated and copper- or gold-only deposits have been discovered in this vast desert area in the past ten years, which are mostly originated from small granitoid intrusions. The Baogutu copper-gold deposit and the Hatu or Qiqiu gold deposits are two well-known examples. Certain techniques of remote sensing were here combined together and effectively used for locating the mineral resources of this kind in the area.

The specific technique, worked out by trial and error, comprises firstly to apply the principal component analysis on the multi-spectral data of ETM+/TM, then to select three principal components from six of them, which can better outline the known difference among rocks in a R (Red), G (Green) and B (Blue) false color composite (principal components 1, 2, and 4 are chosen in this study), afterwards to transfer the composite into the H (Hue), S (Saturation), and I (Intensity) space and finally to display them using a false color composite again. Importantly, this is very helpful to distinguish small intrusions from the vast country rocks and the effectiveness of the mineral prospecting could be further intensified by the concurrent use of certain alteration mineral mapping methods.

Theoretically, the principal component analysis can reconfigure the variables represented by the multi-spectral data of ETM+/TM through eliminating the correlated or redundant parts. This is the reason why the contrast among rocks is notably enlarged. Besides, H (Hue), S (Saturation), and I (Intensity) are three separate components in the color space. The red, green, and blue layers in a new false color composite are defined by these uncorrelated HSI components (or IHS and HIS, etc., choose the best one by test). It is them that further make the difference among rocks clearer. As we know, the RGB-HSI transformation and H (Hue), S (Saturation) and I (Intensity) false color composite were mostly used in certain non-geological fields before, such as the medical image enhancement and the burned land mapping. The effective application to geology of this time shows their wide adaptability. 
This study eventually led to the discovery of three copper and two gold mineralized locations through the ground inspection, which are all related to small granitoid intrusions. As mentioned above, small intrusion-related mineralization marks West Junggar. As shown in this study, though, many small intrusions are actually neglected by the present geological maps at 1:200,000 scale (nation-wide available) or even by those at 1:50,000 scale (about a quarter of China). This implies that the technique of remote sensing introduced here is really of use. It can be also considered in the similar areas elsewhere.

Furthermore, high-resolution Quickbird data were also used for unraveling the details of targets and for locating the analogs in the proximity of mineralization outcrops. Conspicuously, the general scanning with ETM+/TM data is well compensated by the detailed examining with high-resolution Quickbird data. This combination makes the remote sensing-based mineral prospecting more economical and practical.

Nevertheless, many small intrusions in West Junggar are actually below 0.1 square kilometer in size or even a couple of hundred square meters. The ETM+/TM multi-spectral imagery has certain difficulties in properly outlining them although the panchromatic band of ETM+ data can partly enhance the image quality. In addition, high spatial resolution Quickbird, Ikonos or SPOT-5 data are expensive and the acquisition date of them is limited or has less choice. Some of data are cloudy, misty or covered by thick vegetation in certain work area. As a result, higher spectral resolution ASTER data and high spatial resolution China Brazil Earth Resources Satellite data (2.36 m for Panchromatic) are currently combined in the further studies in order to gain the more practical methodology of targeting unknown mineral resources.

\section{Acknowledgments}

Three anonymous referees of Remote Sensing are thanked for their suggestions for the improvement of the paper. The study was supported by the Special Fund for Basic Scientific Research of Central Colleges (NO. CHD2011SY013), Chang'an University, China.

\section{Conflict of Interest}

The authors declare no conflict of interest.

\section{References}

1. China Geological Survey. Technical Standards of Regional Geological Survey (Scale 1:250000), DD2001-02 (in Chinese); China Geological Survey: Beijing, China, 2001.

2. China Geological Survey. Technical Standards of Regional Geological Survey (Scale 1:50000), DD2006-XX (in Chinese); China Geological Survey: Beijing, China, 2006.

3. Grebby, S.; Cunningham, D.; Naden, J.; Tansey, K. Lithological mapping of the Troodos ophiolite, Cyprus, using airborne LiDAR topographic data. Remote Sens. Environ. 2010, 114, 713-724. 
4. Liu, L.; Zhou, J.; Yin, F.; Feng, M.; Zhang, B. The reconnaissance of mineral resources through ASTER data-based image processing, interpreting and ground inspection in the Jiafushaersu area, West Junggar, Xinjiang (China). J. Earth Sci. 2013, in press.

5. Chai, G.; Naldrett, A.J. The Jinchuan Ultramafic intrusion: Cumulate of a high-Mg Basaltic Magma. J. Petrol. 1992, 33, 277-303.

6. Ninomiya, Y.; Fu, B.H.; Cudahy, T.J. Detecting lithology with Advanced Spaceborne Thermal Emission and Reflection Radiometer (ASTER) multispectral thermal infrared "radiance-at-sensor" data. Remote Sens. Environ. 2005, 99, 127-139.

7. Liu, L.; Zhuang, D.F.; Zhou, J.; Qiu, D.S. Alteration mineral mapping using masking and Crosta technique for mineral exploration in mid-vegetated areas: A case study in Areletuobie, Xinjiang (China). Int. J. Remote Sens. 2011, 32, 1931-1944.

8. Nair, A.; Mathew, G. Lithological discrimination of the Phenaimata felsic-mafic complex, Gujarat, India, using the Advanced Spaceborne Thermal Emission and Reflection Radiometer (ASTER). Int. J. Remote Sens. 2012, 33, 198-219.

9. Aydal, D.; Ardai, E.; Dumanlilar, Ö. Application of the Crosta technique for alteration mapping of granitoidic rocks using ETM+ data: Case study from eastern Tauride belt (SE Turkey). Int. J. Remote Sens. 2007, 28, 3895-3913.

10. Amer, R.; Kusky, T.; Ghulam, A. Lithological mapping in the Central Eastern Desert of Egypt using ASTER data. J. Afr. Earth Sci. 2010, 56, 75-82.

11. Amer, R.; Kusky, T.; Mezayen, A.E. Remote sensing detection of gold related alteration zones of Um Rus Area, Central Eastern Desert of Egypt. Adv. Space Res. 2012, 49, 121-134.

12. Gad, S.; Kusky, T. ASTER spectral ratioing for lithological mapping in the Arabian-Nubian shield, the Neoproterozoic Wadi Kid area, Sinai, Egypt. Gondwana Res. 2007, 11, 326-335.

13. Rowan, L.C.; Mars, J.C.; Simpson, C.J. Lithologic mapping of the Mordor, NT, Australia ultramafic complex by using the Advanced Spaceborne Thermal Emission and Reflection Radiometer (ASTER). Remote Sens. Environ. 2005, 99, 105-126.

14. Gabr, S.; Ghulam, A.; Kusky, T.M. Detecting areas of high-potential gold mineralization using ASTER data. Ore Geol. Rev. 2010, 38, 59-69.

15. Rajendran, S.; Nasir, S.; Kusky, T.M.; Ghulam, A.; Gabr, S.; El-Ghali, M.A.K. Detection of hydrothermal mineralized zones associated with listwaenites in Central Oman using ASTER data. Ore Geol. Rev. 2013, 53, 470-488.

16. Ciampalini, A.; Garfagnoli, F.; Antonielli, B.; Ventisette, C.D.; Moretti, S. Photo-lithological map of the southern flank of the Tindouf Basin (Western Sahara). J. Maps 2012, 8, 453-464.

17. Ciampalini, A.; Garfagnoli, F.; Antonielli, B.; Moretti, S.; Righini, G. Remote sensing techniques using Landsat ETM+ applied to the detection of iron ore deposits in Western Africa. Arab. J. Geosci. 2012, doi: 10.1007/s12517-012-0725-0.

18. Leverington, D.W.; Moon, W.M. Landsat-TM-based discrimination of lithological units associated with the Purtuniq Ophiolite, Quebec, Canada. Remote Sens. 2012, 4, 1208-1231.

19. Crosta, A.P.; Moore, J.M. Enhancement of Landsat Thematic Mapper Imagery for Residual Soil Mapping in SW Minas Gerais State, Brazil: A Prospecting Case History in Greenstone Belt Terrain. In Proceedings of the 7th International Conference Applied Geologic Remote Sensing, Ann Arbor, MI, USA, 2-6 October 1989; Volume II, pp. 1173-1187. 
20. Fraser, S.J. Discrimination and identification of ferric oxides using satellite Thematic Mapper data: A Newman case study. Int. J. Remote Sens. 1991, 12, 635-641.

21. Torres-Vera, M.A.; Prol-Ledesma, R.M. Spectral enhancement of selected pixels in Thematic Mapper images of the Guanajuato district (Mexico) to identify hydrothermally altered rocks. Int. J. Remote Sens. 2003, 24, 4357-4373.

22. Ranjbar, H.; Honarmand, M.; Moezifar, Z. Application of the Crosta technique for porphyry copper alteration mapping, using ETM+ data in the southern part of the Iranian volcanic sedimentary belt. J. Asian. Earth Sci. 2004, 24, 237-243.

23. Girouard, G.; Bannari, A.; El Harti, A.; Desrochers, A. Validated Spectral Angle Mapper Algorithm for Geological Mapping: Comparative Study between Quickbird and Landsat-TM. In Proceedings of XXth ISPRS Commission 4, Istanbul, Turkey, 12-23 July 2004; pp. 599-604.

24. Waldhoff, G.; Bubenzer, O.; Bolten, A.; Koppe, W.; Bareth, G. Spectral Analysis of ASTER, Hyperion, and Quickbird Data for Geomorphological and Geological Research in Egypt (Dakhla Oasis, Western Desert). In Proceedings of The XXI International Archives of Photogrammetry, Remote Sensing and Spatial Information Sciences (IAPRS), Beijing, China, 3-11 July 2008; Volume XXXVII, pp. 1201-1206.

25. Lin, A.; Guo, J. Co-seismic surface ruptures produced by the 2005 Pakistan M w7.6 earthquake in the Muzaffarabad area, revealed by QuickBird imagery data. Int. J. Remote Sens. 2008, 29, 235-246.

26. Youssef, A.M.; Pradhan, B.; Sabtan, A.A.; El-Harbi, H.M. Coupling of remote sensing data aided with field investigations for geological hazards assessment in Jazan area, Kingdom of Saudi Arabia. Environ. Earth Sci. 2012, 65, 119-130.

27. Shen, P.; Shen, Y.; Liu, T.B.; Meng. L.; Dai, H.W.; Yang, Y.H. Geochemical signature of porphyries in the Baogutu porphyry copper belt, Western Junggar, NW China. Gondwana Res. 2009, 16, 227-242.

28. Yu, X.D. The geological-geochemical prospecting model and its results of the Hatu gold deposit, Xinjiang (in Chinese). Geol. Explor. Non-Ferrous Met. 1998, 7, 27-30.

29. Zhang, B.; Zhou, J.; Wang, J.N.; Ma, Z.G. Ore prospecting using multi-information in the Darbut Suture, Xinjiang (in Chinese). Contrib. Geol. Min. Res. 2009, 2, 166-171.

30. Xinjiang Bureau of Geology and Mineral Resources. Geological Map of Wuerhe Region (1:200000), L-45-XIV (in Chinese); Internal Report; China Geological Survey: Beijing China, 1980.

31. Xinjiang Bureau of Geology and Mineral Resources. Geological Map of Hebukesaier Region (1:200000), L-45-VIII (in Chinese); Internal Report; China Geological Survey: Beijing, China, 1986.

32. Feng, Y.; Coleman, R.G.; Tilton, G.; Xiao, X. Tectonic evolution of the west Junggar region, Xinjiang, China. Tectonics 1989, 180, 729-752.

33. Zhang, Q.; Wang, C.Y.; Liu, D.Y.; Jian, P.; Qian, Q.; Zhou, G.Q.; Robinson, P.T. A brief review of ophiolites in China. J. Asian Earth Sci. 2008, 32, 308-324.

34. Xiao, X.C.; Tang, Y.Q.; Feng, Y.M. The Tectonics of Northern Xinjiang and its Adjacent Areas (in Chinese); Geological Publishing House: Beijing, China, 1992.

35. Zhang, C.; Huang, X. The ages and tectonic settings of ophiolites in West Junggar, Xinjiang (in Chinese). Geol. Rev. 1992, 38, 509-524. 
36. Shen, P.; Shen, Y.C.; Liu, T.B.; Pan, H.D.; Meng, L.; Song, G.X.; Dai, H.W. Discovery of the Xiemisitai copper deposit in Western Junggar, Xinjiang and its geological significance (in Chinese). Xinjiang Geol. 2010, 28, 413-418.

37. Yin, Y.Q.; Li, J.X.; Tang, H.S.; Hu, X.P.; Chen, D.J.; Qiu, Y.J., Ma, Z.M. Discovery of associated cobalt in Kuoerzhenkuola gold deposit and its geological significance for exploration (in Chinese). Min. Res. Geol. 2003, 17, 1-5.

38. Yin, Y.Q.; Li, J.X.; Hu, X.P.; Qiu, Y.J.; Chen, D.J.; Ma, Z.M. The Buerkesidai supergene-structural altered-rock type gold deposit in the Sawuershan, Xinjiang (in Chinese). Geol. Prospect. 2004, 40, 1-6.

39. Chander, G.; Markham, B.L.; Helder, D.L. Summary of current radiometric calibration coefficients for Landsat MSS, TM, ETM+, and EO-1 ALI sensors. Remote Sens. Environ. 2009, 113, 893-903.

40. Singh, A.; Harrison, A. Standardized principal components. Int. J. Remote Sens. 1985, 6, 883-896.

41. Gonzalez, R.C.; Woods, R.E. Digital Image Processing, 2nd ed.; Prentice Hall: Upper Saddle River, NJ, USA, 2002.

42. Prasad, K.; Prabhu, G.K. Diag-AID: A diagnostic aid for medical image enhancement using colour coding and modified histogram equalisation techniques. Int. J. Med. Eng. Inform. 2011, 3, 223-233.

43. Koutsias, N.; Karteris, M.; Chuvieco, E. The use of intensity-hue-saturation transformation of Landsat-5 thematic mapper data for burned land mapping. Photogramm. Eng. Remote Sensing 2000, 66, 829-839.

(C) 2013 by the authors; licensee MDPI, Basel, Switzerland. This article is an open access article distributed under the terms and conditions of the Creative Commons Attribution license (http://creativecommons.org/licenses/by/3.0/). 